\title{
石油的成因問題和它的解决途徑 ${ }^{(311)}$
}

\author{
C. И. 密洛諾夫
}

二十世紀的初葉，標誌着石油成因論中無機 派與有機派的尖踛的邽争, 前者由Д. И.孟德力葉

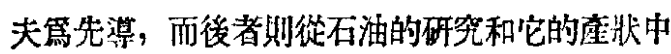
找到了融多新論摭, 來登實他們的學說。

在討論石油的有機成因說中，我國的地質家 佔着前線的位䠄，當特許多諭據中之一，就是在石 油中墢現了一種具有旋轉偏光面的碳 氢化合物 (以後简程猤)。造祇是在動物質中才有的一種特 性。不過當時我們對於石油碳床學和石油成份的 知識是很有限的。

石油成因的無機派學者們，在從碑首中大量 石油的聚程, 就是馀, 造成了從深處移棲(Murpe-

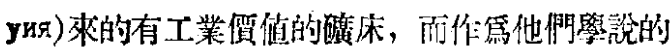
重要論㨜。非常明顯，在這些情况中，一倜最尖銳 的問題, 正像 H.M. 占勃金所察的,就是造成砾床的 環境問題8 。古勃金把研究者分第雨派, 就是原生 派和次生派。前者以篇石油產生的展位就是它現 在存在的地力，而後者，则主張石油是從地教深處

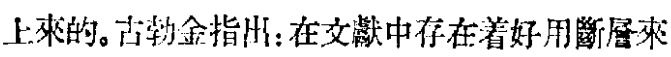
解說的㥧向，而對於阿普希助 (Anuepor) 油时，也 有一種把它作焉酸脉的看法。祀在極少的例子小中， 他恱: 我們看到研究者是用自己的觀察,作䉆事賽 的根據的。大多数的例子，則常把事實變第研究者 主觀的意向和同情。而觀察不詩, 研究範圍又非常 铁小。

賞封一储熱烈的有機派學者，如大家所知的 K. И, 卡里荻基 ${ }^{12}, 13$ 篇了科護他的學說, 他提招 了非常幼稚的論噳, 在現在嚴謹的學者們看來, 可 謂笑談而够不上批部的。篦如他提H把把一種動物 “30octpa” 的遗體作第座生石油原始質料的意見。

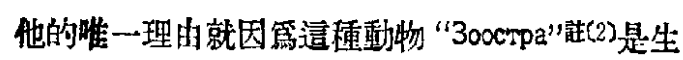
長在砂地上的, 他找到它被埋覆了, 但仍能保存原 來的形相在阿普希朗的巴廟展的沉積中。從唯心
的觀點出墢，卡里荻基一坐中頑强地反對石油移 棲的性能。在他的賔際找油工作中，也用了背样展 理呍作第指導，但不承認石油蓄精與背科替曲的 關係。篇說明這種關係，他提出了在地層內物筫的 中間分溜運動正(耳)(Мөжфракционныипередвижөние) 的意胃，並以此作篇石油濫可能形成在背斜裙曲 中的十分幼稚的理論。

廣泛地長侍間地被這個無機成因說所統治, 許多人受了孟德力葉夫的影響，會把在實驗室中 畑的合成試驗, 與當時地質科學的成就相配合, 作

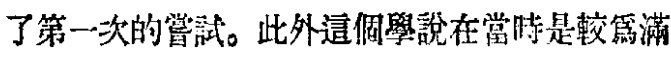
意而文較鹄賽際的。

孟德力䕀夫學說的偪值, 包含在它首先能綜 合了化學和地質學的成就，這樣就集定了在石油 成因問題上地球化學研究的方向 ${ }^{15}$ 。但是孟德力 葉头時常提醒人們, 他所說的就是一種㡐测, 需要 進一步的研究; 這裹, 他又補充說: 汥有腤测, 就 不可能解說石泊的成因，因篇這䅲並非在我們眼 前做成的現像，是不可能自己來表逹的，並且如 果沒有關於過程的記傤，就然法作潐確的分析和

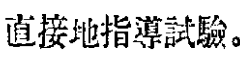

B. И.范爾那特斯港在賞侍就指出: 石湤踓以

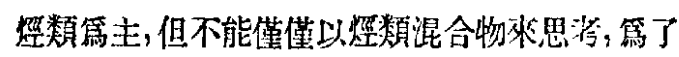
推斷石油的成因, 决不能忽略了在其中纱存在着 氧、氮和硫的化合物。因此, 佾使我們不能否認

註[1] 1951年11月28日古勃金80藏生日紀念會上

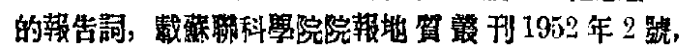
19-29面。

註[2]通是卡里苂基的一種幻想，他以多肉少骨

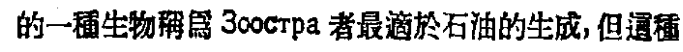
生物, 是否存在, 頻成疑間。

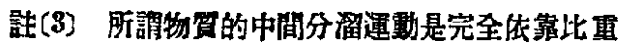
的不同, 油輕水亚, 油往上年水往下沉, 使地眉也故了 䙫曲。 
在大地深處造成烴類的可能, 是在不可知的物理 的和北会的環境下，我們又没有任何根據來推想 石油中氛、硫和氧的化合物是在大地深處造成的， 而通些分子的來源，在目前已研究明白毫無疑閣 了。范西那粹斯基會正確地結論說: 石油的化學 研究，不能給予基本的論據隶說明墚處造成的煙

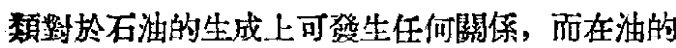
原始質料必須從動物方面搜筧，祜有這些生物，

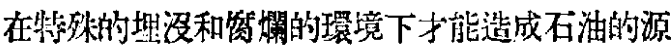
泉。

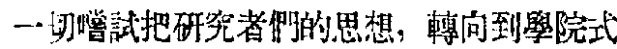

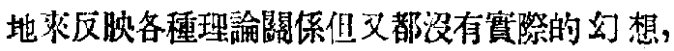

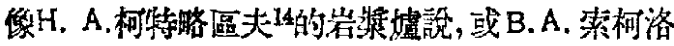
夫的行星說一一未星、上星、天王星、海王星等， 對於科學都是無貢獻的。在火成岩的空隐或裂縫 中存在的涯青或石油，在沼有生油屡(Нефтепроиз

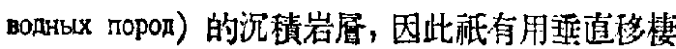
來解說的例子，都不能作篇石油深成說的理由1。古 勃金會正確地說過：火成岩的作用，僅在洪備空 間,造成孔道，以供石油的積聚，但它們本身不能 望生石油。此外，又常常使酸物富集它的原因也浔 有經過研究。

經過很長特間，目於地面上倞在看大量清楚

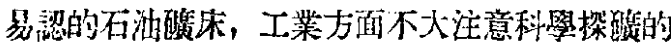
才法。但不久石油的需要激增，如用於動力然料力j 面，同時工業的發憵，都需要開探新的碳床。當第 一次世界大戰結束後，利用科學從事䆩際探油骼 到特别的急追。俄國石油工業在國有化之前, 也走 上了與外國同㯲的道路。不過管洔政府注意的是

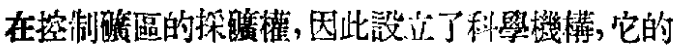

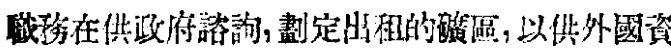
本家的開探。這就是我國石浘科學不能像外國同 楱發星的原因。

相反的,篇科學研究石油的完全有利的環境，

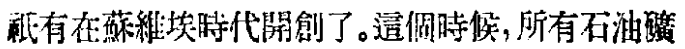
的開探權，都踏人民所有。

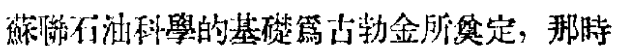
關於不油成因問題的情况，他了解得很清楚，如他

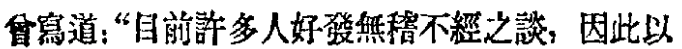

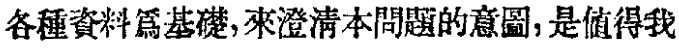
人注意的”。我們的時代，標誌着蘇聯學者們一系 列新事賽的發現，製可反政地解决了石油有機成
因說。早在 1919 年 H. B. 謝林斯基 ${ }^{11}$ 在巴爾哈希 (Балхаw)的阿里古斯克 (Aлиryльск) 的港湖中，探

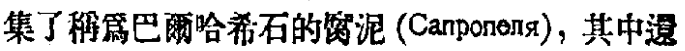

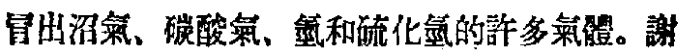

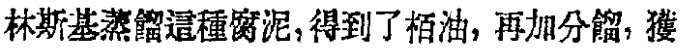
得了汽油、嬁油和重油，從重油中㛛林斯基找到了

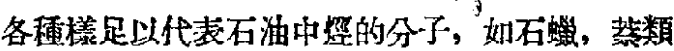
和芳香族的涇類。在後來的工作中，謝林斯基又 指出動物和植物的殘遺體中存在着棕调酸和硬脂 酸以及其他的東西, 經過了氯化鉙的媒觸作用, 並在比較不高的温度下（攝氐 $150^{\circ}-400^{\circ}$ ，慥成了 一種兴品, 在化學成分、物理性質和外表形態上 都與石泊相似。因此謝林斯基就鼠道: “化學家麇 這樣成功了把天然的有機物變成石油娱的油類, 並且可以指出由於天然物啠的成分和結陆，就可

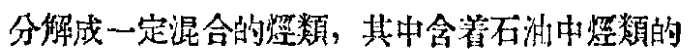
各種標淮的代表”。

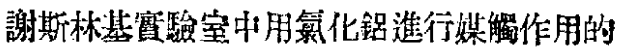
研觉, 有一缺點, 就是這種媒觸辫，天然界中並不 你在, 因此需用在喽床中存在的岩石研究，以决定

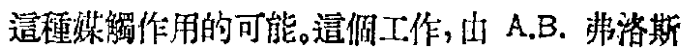
盼担任。他斷定在天然界可以满足造種條件的就 是倣酸鋁一一種粘土。這程粘土在巴闻的含油 砂居和曲古洛夫(Шугоров)的白雲岩中都經發現。 弗洛斯脫指出在粘土與偍力的聯合影響下，並由

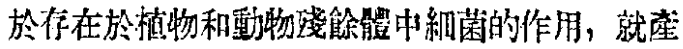

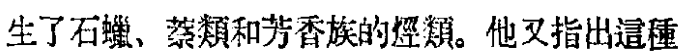
粘上, 不起光性反應，可能舅於動植物殘餘體中的 一種組合。

這㧼，蘇聯的化學家們，在謝林斯基的湎尃 下，用賽驗宝的環境，指登了從有機物漟品中，並 在適合於石油硌床地質的環境下，有造成各種各 榡石油中烴的可能。

在本世紀的三上年代我們國家出現了一㑑對 於討諭石油成因閣䟎有重要意義的墢現。我親自 看見了 H， . . 烏興斯基 和 T，几，金士㜑葛一卡 拉奇區娃在皮皮一依排脫和蘚拉哈紟(Биби-Эи и Сурахоно) 的鉆服水中發現的細菌。後來在美国 的石油硔㡷中也發現了細菌。

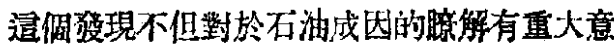

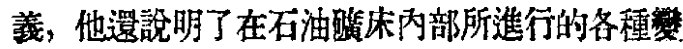

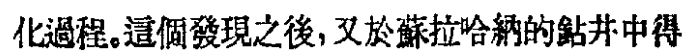


到了一種從1700公尺深處出來的紫色水，掉研究

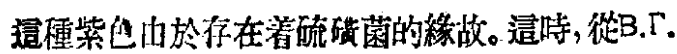
橉洛賓的工作，大家知道這種細菌在等平方公分 三下順的厎力下也不玫政失生命。從鉆井水的數 量講, 地解上和菌混進去是不可能的。但是否這種

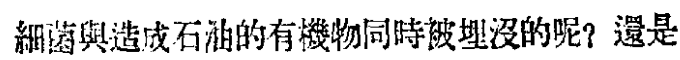
它隨管地下水沿地眉而入的呢? 如所週知, 最大 的細菌, 長不渦三微米它的容瓄就不過 10-8 立方

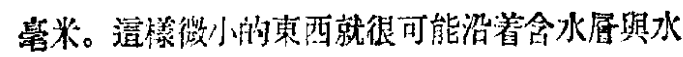
相混流入深緊。

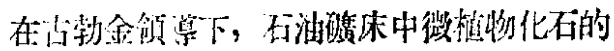

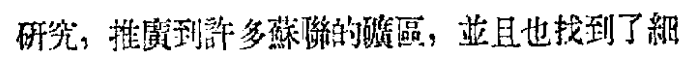

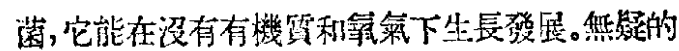
造是地筧上很古的生物。不過這種墢現的細菌,

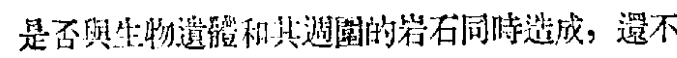
很明白。微生物學的研究指出，硫唡菌能把地湎㛧 不中吸收的石油游滩出來, 因此它對於石油的移 楼和程聚有重大影響。細菌的作用足以說朋在硌 床㬴部油水相鄰的地㶾它能諮扠油的比重。10,25

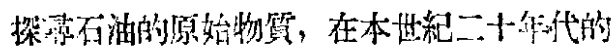
後分:期我國有A.Д.阿爾字格利断基1, 美國有脫拉

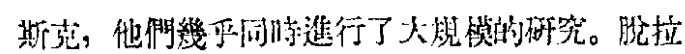
斯克研究現代海洋中的泥上沉数而阿霖高侪利斯

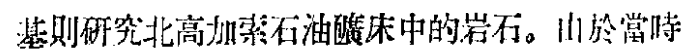
研究方法不够完善, 所得結果亚不很奵,

占勃金對於石油成因問題有重大影響，笏了

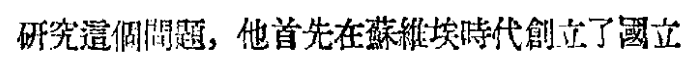
石油研究所而當蘇聯科學院搬到莫斯科時，他又

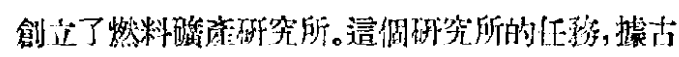

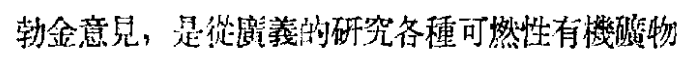

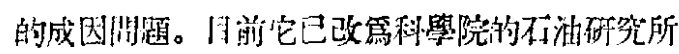
了。

從有機成因說的立場出發，古勃金認篇石油 的生成是連䅥的，與它其生岩石的生成是分不閒

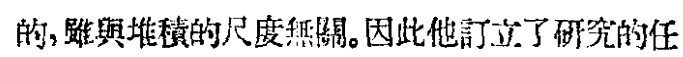

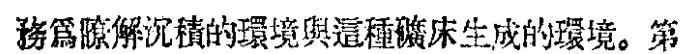
一個任狋，他鼠道: 是研究酸床的地質構遥，和石 油本身及其園岩間廣泛的關係。第二個任務是從 一般的觀察來砰究事實和現貌，同時也建立起理

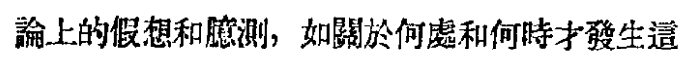

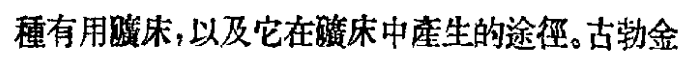

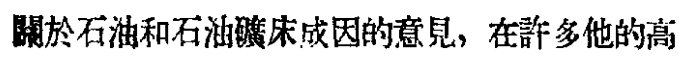

加装東南部和北部的油持論文中, 已詳細地論迅 了。在國際地質會請的報告中以及他所著不油諭 一書中也都有概捗的論远。

對我們有眮味並於石油成因有關的是占勃金 關於高加索東南部地質構造和含海性的工作。他 得到這樣的結詥: 高加丞的地質構造, 含油性以及

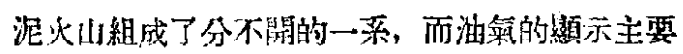
的是由於同一的原因，它代表着地質發府上一系 列分不開的作用。這储作用湔始在高加索大地槽,

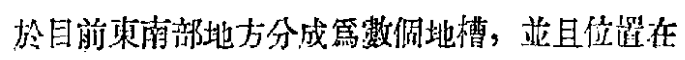
有些高起的和有些低陷的地區，而形成了高加索

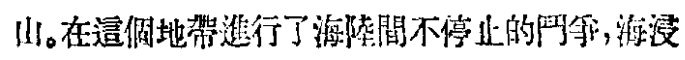
和海退的現象, 交替發生, 這㮈在適當環境之下,

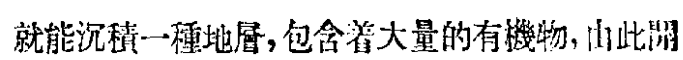

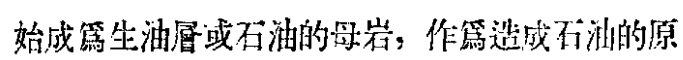
料。高加卖附近大陸上的强烈浸鸽, 加速了沉锖物 的堆啨，加速了有機物的掩埋，蕜使它沉隆到很深

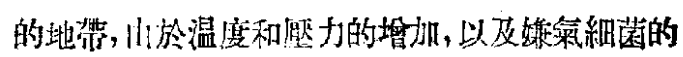

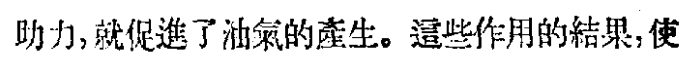

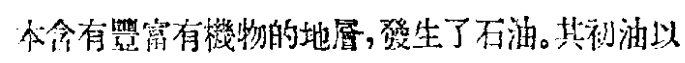

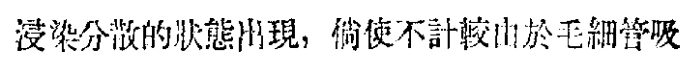

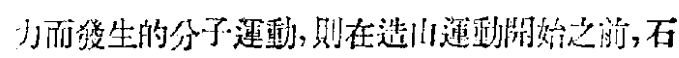

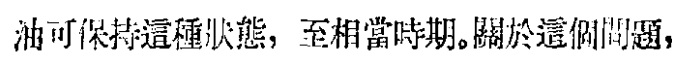

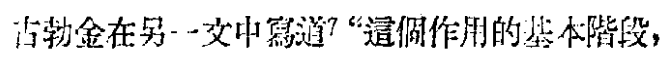

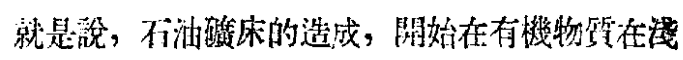
我帶沉積中的積聚……在各種因素的力量下（如 紨菌的簿解，温度、歷力等等）使有機物變成石油

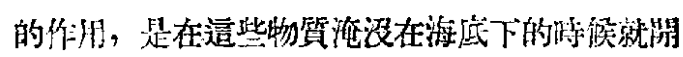
始的, 它一遖姃長到淹沼到梁處, 維且在较高的 温麻和敢力之下。開炲造成浸染分散的石油, 是

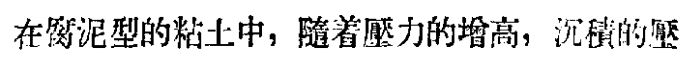
紸, 以及其他沉積以後的變化, 浸染分散的不消和

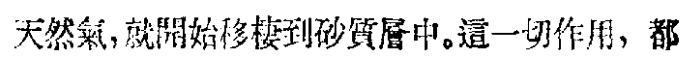

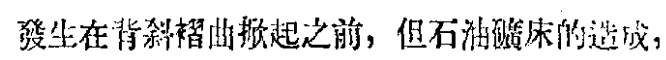

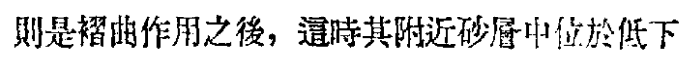
處而在水面上的油和氣，就向最高的地點泹上. 來 了。"

我要向我們年輕的地質學家們提醒，饬勃金

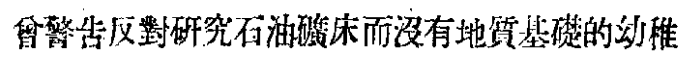
作風。他赾議這程研究一定要與整储地區的地質 情况聯繫起來。在偉大的十月社會革命前一年, 他僧舁道: “在整凮地筫構成的環境上，對於所有 


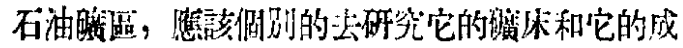
分。”

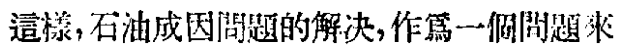
看,應副在科學各部門的複雜笻園内隶解决。從這 點师發, 古勃金就進行了微植物的研究。不過, 這

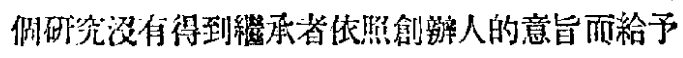
適當的重視，区此在占勃金死後不久，這㮯研究就

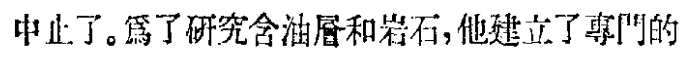
地球化學賽驗室; 篇了解决移楼閣題, 就發虽了

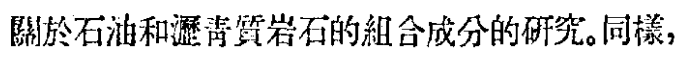

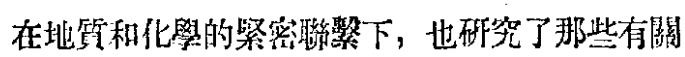

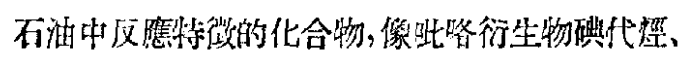
醛類化合物等等。在地質學的各部閉中，他特

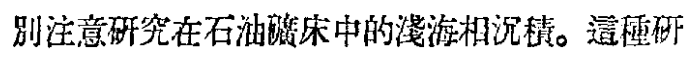
究，依照雨個方向進行。其中之一是以重建含油 居特代的地理情况篇任務, 其他则第研究落油居 的分俳和它的主要成分。，這榡，在古勃金领管下 的研究所中，在藻維埪的洔代，終於實現了他的

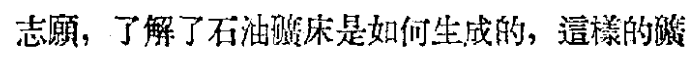
林,正如他所察的, 是變化莫测的, 如果是赤手空 拳, 涰有地質、化學和物理的通力合作是無法進行 的。

古勃金所主張的石油生成不斷進行說，若干 研究者有洔不能完金了解, 谌至曲解。繁如 A. $\Phi$.

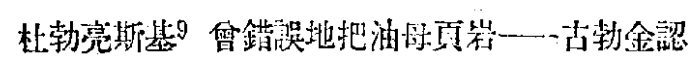
第是低發育的石油…作篇石油的原生留料; 因 此，發鼠了一储石油在地筫洔代中逐渐變化的學

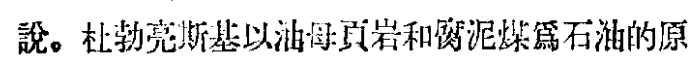

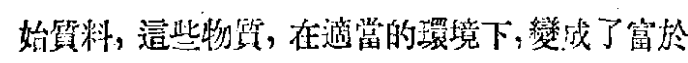
氮、硫、氧的高分子式的多環烴，而代替了管随質

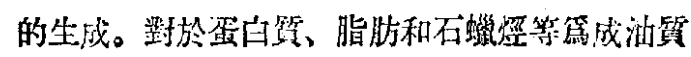
料, 杜勃亮斯基却認第並不重要。在進一步的涯青 化，在媒解㓩和温度的影響下，那些非烴化合物成 第 $\mathrm{CO}_{2} 、 \mathrm{NH}_{3} 、 \mathrm{H}_{2} \mathrm{~S}$ 和 $\mathrm{H}_{2} \mathrm{O}$ 而逐漸沙失，而年一先造战

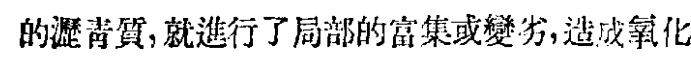
型青、粘性栢油和重饪油性的各種石油。其後打逐

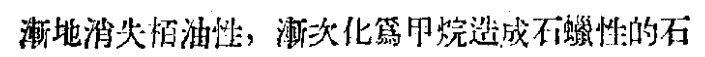
油, 最後则變篇天然氣。

近年來B.A.烏斯賓期基進行了國內外各種油 類在地域上和在層位上分倠的研筦。他的結諭是 大部份油性的不同，是次生作用的結果。原始石 油，大敨相䌷，它是一種橙的，含有石䗨、用烷和
環烷的石油; 而重的不含在蠟富於柏油的石油，都 是整油的衍生物。

岛斯賓斯基又謂石油中環性成分的積聚，與 氯化作用有關。如不会石䗨的督青基石油代表一 種次生石油, 它是由於镸中的烷部分被氧化陑成。

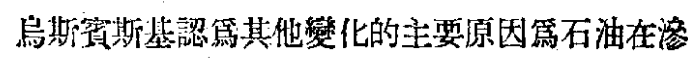

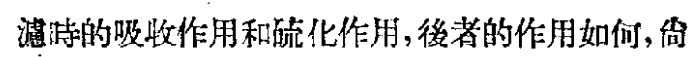
未完全了解。烏斯賓斯基與杜勃亮斯基不同，認篇 石油是從政浸在岩石中有機的輕貿容易流勤的東 西造成的。它的結構是脂肪厤化合物的, 與多環的

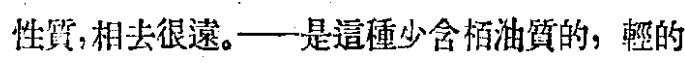
以晥䉆主的原始質料或原生石油皘聚於岩庴 中, 其後在缺㴋環境下, 經過氧化作用, 就造成了 各種不同的較重的石油, 再經在多氣環境下的氧

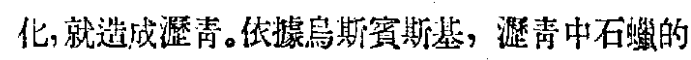

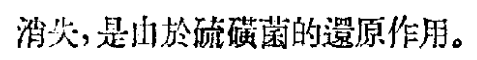

纱使朴勃亮斯基的學詨，因篇不能行合於地 質學上關於石油原生質的理諭，不能滿足我們閶

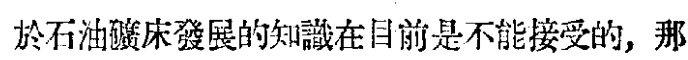
米，烏斯䆩斯基的說法，似乎较近於篇古勃金所發

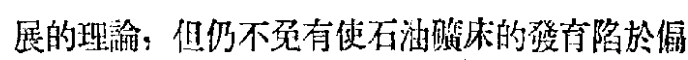

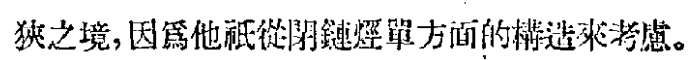
必須没想, 石油喽床中進行着十分椱雜的作用, 一 方面使石油甲烷化，另方面使之源青化。烏斯賓斯 基和杜勃亮斯基利用化學分析和工業分析的統計 資料夾獬說石油础床的造成, 還不能認篇是基本 的法则。

十多年前, 在阿普齐期经岛上，後桃又在恩巴

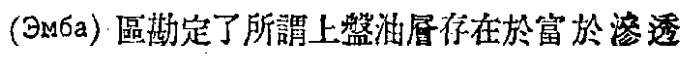
性的储油居中。在阿普乔朗, 這種油首中油水接 觸面的倾鿇有時可達三十度, 而它的水平分作, 可 连數十數百以至數干公尺之蹗。這種不正常的震

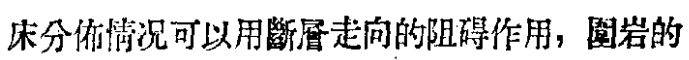

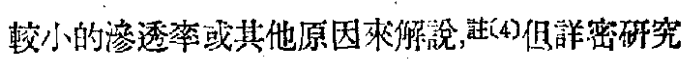
這些解休後，以上原因，都不能滿意。這漛就使一 部份研究者倾向於石油在含水展的地下自然環境

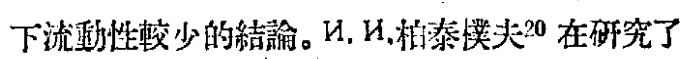

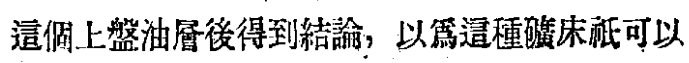

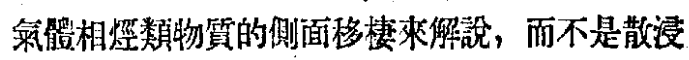
在含水居中被毛細管吸着的液體相。他又假想石 油的原始物筫是甲烧，它是含讶特多的分子，是在 沙泡或粘土中的還原狀態下造成的。砸有後來的 
氧化作用, 在蕃油展的氧化䜞作用下, 才由於逐 濑消失氫，增汌氧，而造成了石油中较袮橉的经 類。但柏㙩楱夫又引引登謝林斯基和古勃金的意見，

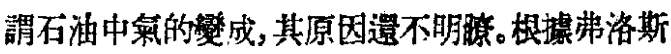
镜 ${ }^{24}$ 謂媒解劑在成油過程中起着主要作用, 而索

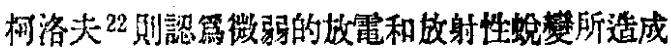

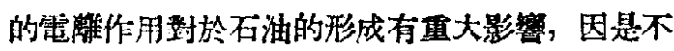

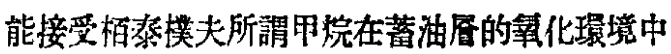
成油再裂楼到含水居中之說。查甲烷成油馀篇不 少地筫學者所主張，包括柏泰椦夫在內，它對於 原生油屡的造成，不是沼有任何根據的。

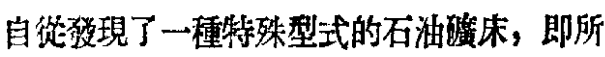
謂液化楞對於石油地質的地下環境有重大意義。

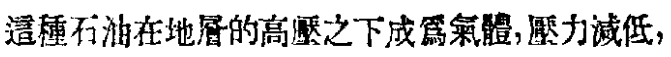
它就凝結。如下所述, 這種㠜結作用，也可在地屏 中進行。近年来㻴境促成了關於缰類混合體在高

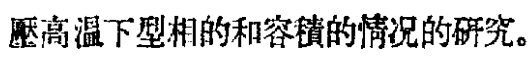

在這方面M,A.卡彼廖尼古夫和T.I.徐材得到

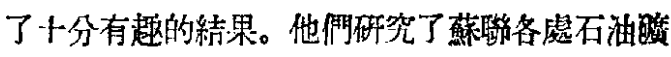

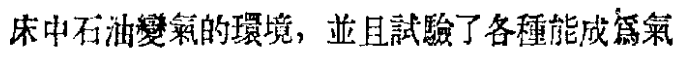

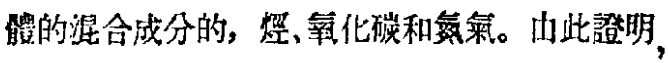
在各種石油中不同的菜能, 在温度 $40^{\circ}-80^{\circ} \mathrm{C}$ 的

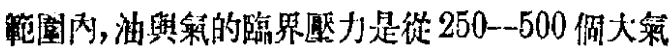
㑛。這樣在某一適合的比例下, 就可知道需要们種 然力, 使不油變成氣體。從此得到結論, 即在地呚 內適當的環境下，石油可以氣體存在，蓝且像获 能一溙的秋楼。石油在策體相的移棲，說明了在 天然界石油移凄的痕跤之不存在，而使 主張次生 境的人，在地居中鉆到了石油後，不㮹陷入迷惑。 同檬，我椚地不需要迷惑於早先觀察的石油在地 居中缺之流動性的事實。對於他們，可把那些關於

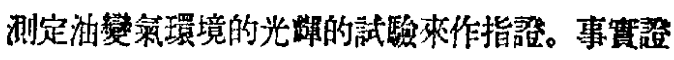

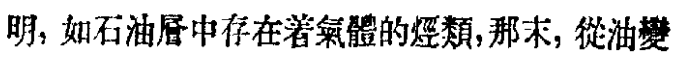
到氣蓝不需要很高的温度和捱力。

近你來關於石油中存在着燈油分子的㳻烷的 研究，也得到了有興趣的結果。這種内 E.C. 巴克 洛夫斯卡雅 $(16,17,18,19)$ 完成的研究, 指出在落干石 油中䒺類是大多數存在的，但在個别例子小它是 不保在的。如我們的恩巴油田中就沼有喽現過, 在

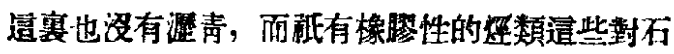

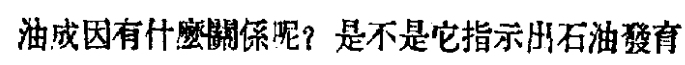
作用的方向胒?
解決石油成因問題的困難，在於目前我們知

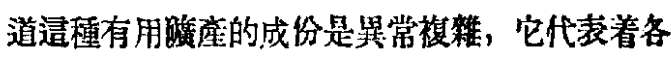
種烴類的複雜的混合體，不同地豆的產品，就有不 同的組合。此外，在這些混合物中，除烴外，還有炭 干量不同的，衍生出來的以含硫、氯和氮篇主的 化合物，以及栢油產物。所有這些複雜的化合物，

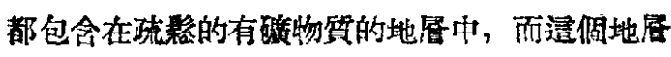
對於它包含的從 $C_{1}-C_{100}$ 複雜給合的垁類以及衍 生出來的斻、氧、氮等也有影響的。另一困難，是通 些䙓雜的混合物在繼續不断的誉化着, 相互的作 用的，椪與储展作用撯。

所有递些作用對於被暏覆的有機質料有關， 是浑有任何疑問的。不過天然有機物不管是植物

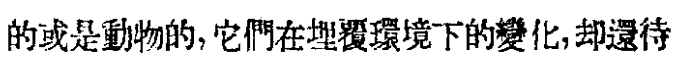
深入研究。綮㩆的，這樣的變化，是在多種因素的 影響下進行的，而义隨着時間起着不同作用的。就 在最早的階段，㘿覆後有機物筫的榜化成油，不可 能與包含的暆物質的地居在地球化學和地球物理 的作用上浔有關係的。此外，不要忘了正如古勃 金所指出的, 石油成因不能視篇一種罚立的作用，

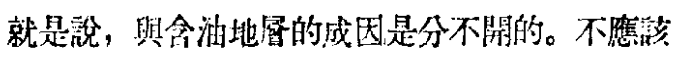
志记，不油的生成是的於從前被径覆的有機物質 經過吘多複雜的天然作用之總合結果。

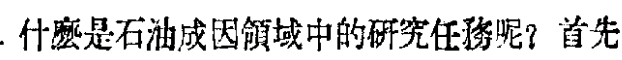
第了瞙解烴類的成因，必須研究透成高制煙類和

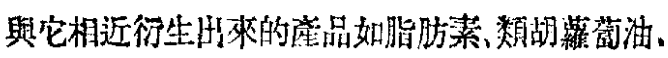
石蠗和其他的生物化學的作用。同樣需要没法找 非微小的生物，它們在一定的㻴境下可以造成经

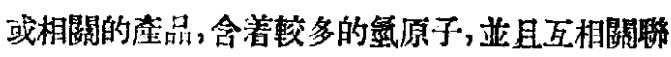
着，而作篇從動物質到石油筫的過渡特性，同封欢

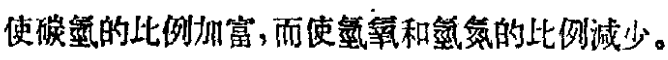

必須瞙解各種有機化合物，首先是镸的熱動 力均衡的條件，要精密㸴究地居中媒虽作用在各

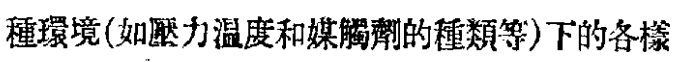

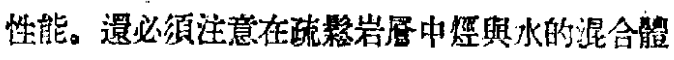
如何分陮和積聚的物理化學的研究。

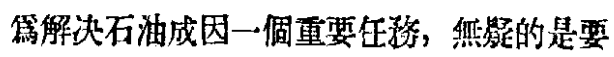

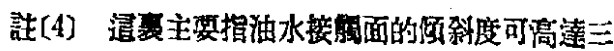

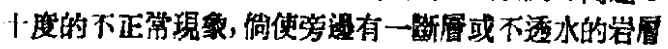

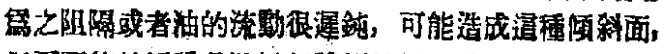

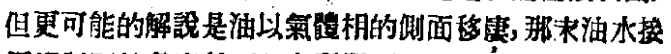
解倾科面的角度就不必有所限制了。 
更正確地膫僻什麼東西代表着石油。可是遖到現 在, 造成石油的煙類、知道的還是不多, 罚至有些 缓類包含在各種汽油中, 而要鑑品石油中更高般 更複雜的烴類, 就需要有新的方法。造核就要加强 對於石油的研究像 C. C. 那美得金所已開始的工 作16.17.18.19。

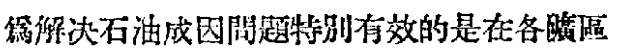
多數油居中去研究各居中個別的佂類以及在探探 工作中油質的變化。這種研究開始佈稙在拿美得 金的躓驗室中, 後來则在 A. B. 托普區業的望聽 室中。此外研究石油中的蛵類, 必須同洔研究非烓 類化合物與地居環境的關係。

同樣重要的是研究石油在酷居中位在的情 况。其中一個重要因素是疏暬地展的存在, 即储油 居的凊在。如岩石學研究所規定的, 這是一種砂 居, 或是有各嵄孔隐的而含柎有機質的岩石, 也可 能篇管有裂繾的各種堅密岩石。造程岩石大部份

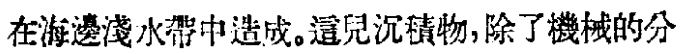
異外，還受過河流的選分作用，並被海波所冲別。 䢜種濱海淺水綮, 也就是後來由移棲結果而造成 油田的區域, 從此鉆井得油。因此, 完全了解, 石油 地筫家篇什麼要從事古地理的研究, 部多人包括 古勃金在肉, 都注意這榈問題。研究石油成因的一 個重要方向是研究產油區储别地展系統的分佈和 它阿的相互關係，以及沉皘作用的循環性。

必須同樣研究储油居的成分, 定出它在储油

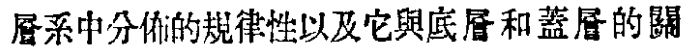

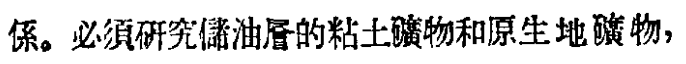
以健明瞭在盆地中沉皘的地球化學的環境篇了研 究岩石形成後的作用, 必須注意後成酸物的研究, 以及所䣓散漫状的少數元素。
䃑究海洋學工作中所挖掘起來的現代沇積 物, 可協助規定储油层造成㭙的環境以及成油初 期階段的地球化學的作用。

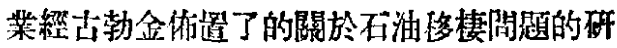
究, 世佔等重要佔谓。照目前情况而諭, 石油不但

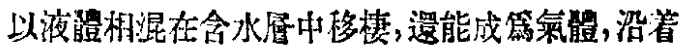

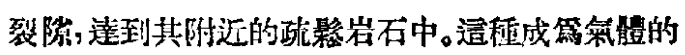
石油，能把岩庴中水分擠走，與之替代，而距其原 生的抟位, 就越來越遠了。這愫就把移棲阳題研究 的任務，放到石油，源青質和岩石的地球化學研究 上去; 同時文發展了從油變氣的赛驗方面的研究。

我們昂已講過古勃金對於石油成因問題的研 究, 發揮了極大的作用。篇了解决造些阔題, 他首 先組織了一储研究所, 㴆就是現在改組後的蘇聯 科學院石油研究所。

占勃金指出了一條路牔，我們必须照着前進， 以侹䡠除地解决石油成因問題, 以健協助辛苦綎 營石油工業的人們探獲可能的大量的石油, 逐是 第建立共産主義社會國民經㴼所必需的，也是篇 保衛偉大的十月革命的勝利和第全世界的和平而 王等所必需的。我相信古勃金的學生們，和古勃金 所無限熱愛的年青的工作者們——將來能够光榮 地完成一種任務的, 這個任務古勃金曾對它表示 過無限忠誠。

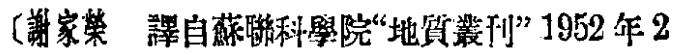
踋19-29面了

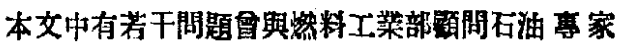

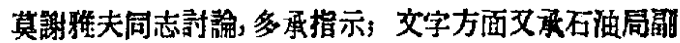

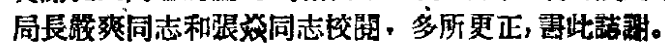




\section{荟考文}

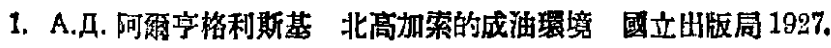

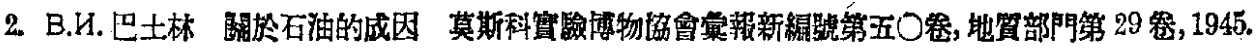

3. В.И. 范爾那特斯基 地球化學論交集 石酒地筫出版局, 1924，

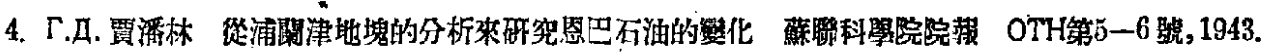

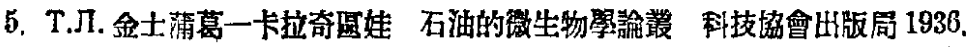

6. U.M. 古勃金 論石油 第二版, 科技坫會出版局, 1937 .

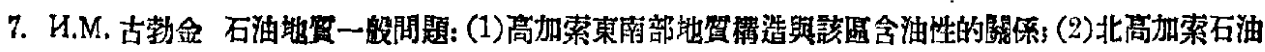

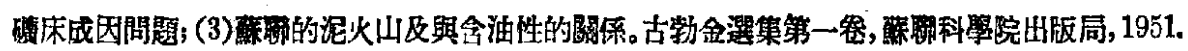

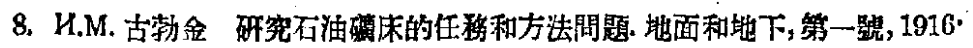

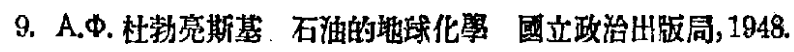

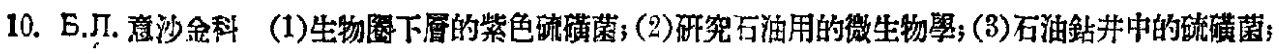

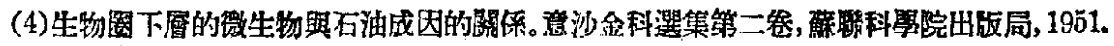

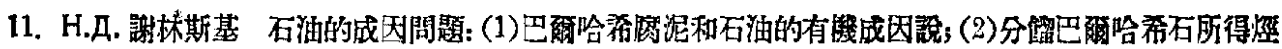

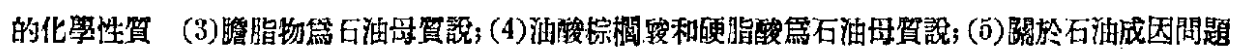

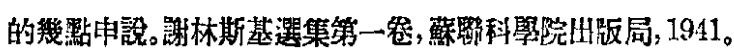

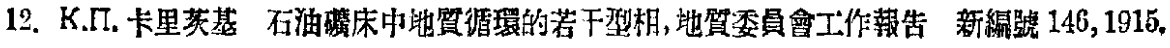

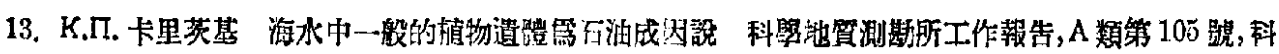
落協會砟究所, 1937 .

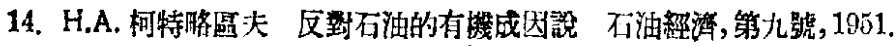

15. Д.И. 孟德力業夫 (1) 石㹨成网的各種學說; (2)北美本雪佛尼亞省和高加索的万油工策。孟氐選集第 十兊。蘇筑枓學院出版局, 1949 .

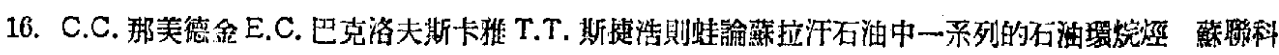
㧳院報告灇刊67 管, 1949.

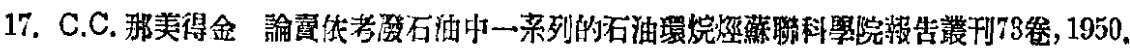

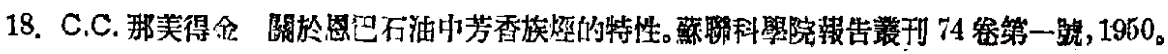

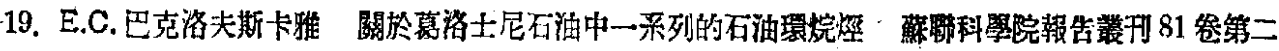
號, 1981 。

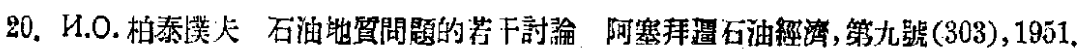

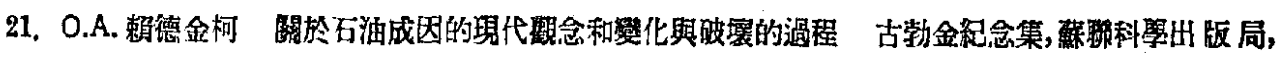
1951 。

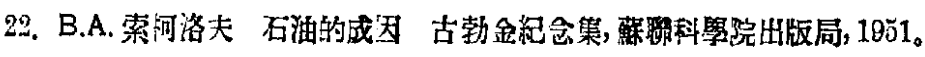

23. B.A., 黑斯賓斯基 O.A. 赖德金柯 關於各種石油類型的成因間題。

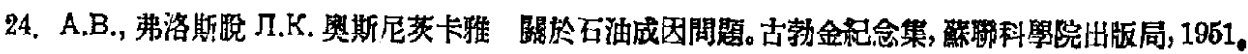

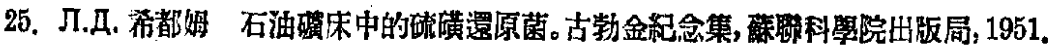

